\title{
Strategy to Stimulate Student's Creativity in Design through Subject of Engineering Design in Department of Mechanical Engineering of Andalas University
}

\author{
Eka Satria $^{1}$, Devi Chandra ${ }^{2}$ \\ \{ekasatria@eng.unand.ac.id ${ }^{1}$, devichandra@eng.unand.ac.id² \\ ${ }^{1,2}$ Mechanical Engineering Department of Andalas University, Padang, Indonesia
}

\begin{abstract}
This paper investigates application of several design techniques to stimulate student's creativity in design of engineering products. The first technique is creative methods,such as brainstorming, synetics, enlarging the search space, while the second technique is rational methods such as objective tree, function analysis, quality function deployment, morphological chart, weighted objective and value engineering method. Both techniques have been previously taught in the subject of Engineering Design, one of required subject in Department of Mechanical Engineering of Andalas University, for $3^{\text {rd }}$ year students.All methods above, whether creative methods or rational methods, theoretically could be used to stimulate the creativity of the students in the design process. The creativity is assessed through application of analytical rubrics in four criteria of assessment. Those are variety of ideas and context, variety of sources, combining ideas, and communicating something new. The result shows that under scale of 1 to 4 , the level creativity for four criteria of assesment are 2.93, 2.79, 2.5 and 2.15 respectively. In general, the average level of creativity is 2.59 , somewhere between category of Creative (Scale 3 ) and Ordinary (Scale 2).
\end{abstract}

Keywords: Design Techniques, Creative Thinking, Analytics Rubrics

\section{Introduction}

Creativity is one key issue in engineering design education. This creativityexists in all individuals, but with different levels. Clearly, some people are more creative than others. According to the psychologist Sternberg [1], the person's creativity can be defined as a function of several attributes, such as: intelligence, knowledge, thinking style, personality, motivation, and environmental context. Among these six attributes, the thinking style and the knowledge are considered as two key attributes that related to each other. According to $\mathrm{Li}$ [2], the knowledge can be a positive or a negative factor to creativity depending on designer's thinking style. Usually, with the increase of knowledge, creativity is likely to rise. However, in another condition, because of the psychological problems, the designer may be stuck in the framework of his knowledge or his xperiences, in this case, the creativity may be go down. From this statement, it can be notified that the way of thinking of designers is considered as the most important attributes in creativity.

In term of design creativity, there are six attributes that have a big impact on it. Those attributes are knowledge, thinking styles, information, computer technology, and uncertainties, anddesign methods [2]. Knowledge and thinking styles have been shortly discussed in the 
previous paragraph.As a function of information, design creativity should considersome information such as competitor products, market of products, etc.As a function of computer technology, design creativity can be definetely improved by using knowledge-base technology, information searching technology, artificial intelligence technology and CAD technology, etc. As a function ofuncertainties, design creativity could be affectedbysome external factors that considered as uncontrolled and unchanged factor in a short time, such as environment and culture. The last, as a function of design method, design creativity can be inspired by a suitable design methodology or procedure. It will be easier for designers if they are assisted by several techniques, or tools in design. This paper focused on investigating the role of the design method in stimulating student's creativity in design process.

According to Cross [3], design methods can be defined as any procedures, techniques, aids or tools for designing. The methods represent a number of distinct kinds of activities that the designer might use and combine into an overall design process. Previously, design methods are conventional and normal procedures of design that must be followed by designers point by point sequentially.Nowadays, there has been a substantial growth in new design procedures. This new method consists of two principal features in design procedures. The first is how to formalize certain procedures of design (called as rational methods) and the second is how to externalize creative design thinking (called as creative methods). The second feature is directly related to the ways of how to stimulate design creativity. The first feature is more commonly regarded as design methods than the creativity techniques, however in its application, it often has similar aims to the creative methods, such as widening the search space for potential solution [3].

Mechanical Engineering Department of Andalas University realize that the creative thingking is a backbone of creativity of design. Therefore this attribute should be owned by the students. The best way to stimulate students in creative thinking is through a design project where it is usually given in the subject of Engineering Design. In this lecture, students are asked to work in a group to solve a specific design problem given by lecturers. Although, during the past five years, the students had succesfully designed some productsas solution of the given problems, unfortunatelly,mostly there were not any new developments or new features from their design. Their products usually are only redesignof several products that were sold in the market. There was almost no creativity shown in their product. At this point, the attribute of creative thinkingas one of the outcomes of the design project was not reached yet. To solve this problems, started from last year, the lecturers tried to adapt the new concept of design method, that combining the two main features; creative and rational procedures, into student's design project.

This paper focuses on how to apply the introduced design method in stimulating creativity of students in design. In the first part of the method, that can be considered as the hardest part of the design, students are asked to generate ideas (problem exploration) for solving the given problem. For this part, students are initially taught to use several techniques to stimulate their creative thinking, such as brainstorming, synetics, and enlarging the search space $[3,4,5,6]$. In the second part, that is aimed to generate and evaluate solutions, students are taught to use several techniques of rational procedure, such as objective tree, function analysis, performance specification, quality function deployment, morphological chart, weighted objective and value engineering method. Although, these techniques are quite procedural in practice, however, they still can be used to stimulate the creativity of the students. Creative method and rational methods are complementary aspects of a systematic approach to design. According to Cross [3], they should be seen as a lifejacket, helping the designer (especially the student designer) to keep afloat, rather than as a strait jacket. The outcomes of this paper is to investigate the level 
creativity of the students in solving the problems of their design projects through application of an analytical rubric.

\section{Creative Methods}

There are several techniques which are intended to help stimulate creative thinking of students. In general, they are used to generate or to increase the flow of ideas, by removing the mental blocks that inhibits creativity, or by widening the search area for solutions.

\section{Brainstorming}

This method is used to generate a large number of ideas. The essential rules [3] of brainstorming are: no critism is allowed, a large quantity of ideas is wanted, seemingly crazy ideas are quite welcome, keep all ideas short and snappy and try to combine and improve on the ideas of others.

\section{Synetics}

Creative thinking often draws on analogical thinking, on the ability to see parallels or connections between apparently dissimilar topics. There are several particular types of analogy [3]: direct analogies, personal analogies, symbolic analogies and fantasy analogies.

\section{Enlarging the Search Space}

A common form of mental blocks to creative thinking is to assume rather narrow boundaries within which solution is sought. Many creative techniques are aids to enlarging the search space [3]; such as: transformation, random input, why? why? why? and counter planning.

\section{Rational Methods}

The rational methods are more commonly regarded as design methods than the creativity techniques, however, in their application, these methods often have similar aims to the creative methods, especially in widening the search space for potential solutions. Several techniques [3] that can be used are: objectives tree (to clarify objectives), function analysis (to establish function), performance specification (to set requirements), quality function deployment (to determine characteristics), morphological chart (to generate alternatives), weighted objective (to eavaluate alternatives) and value engineering (to increase or maintain the value of a product).

\section{Design Strategy}

A design strategy describes the general plan of action for a design project and the sequence of the particular activities which designers expect to take through the plan [3]. The purpose of having strategy is to ensure that activities remain realistic with respect to the constraints of team, resources, etc, within which the design team has to work. The design strategy consists of two features; the first is a framework of action and the second is the used tactics to fulfill the framework. This paper generally devides the framework of action into 3 groups: problem exploration, problem specification, alternative solution. While, for the tactics, all techniques described in Section 2.1 and 2.2 can be freely chosen in the design process. 


\section{Methods}

The general methodology of this research is oulined as follows:

1. Lecturers describe all techniques of creative and rational methods in front of the class. The teaching should includes with giving examples and homeworks.

2. Lecturers describe the theme of design projects.

3. Although the design project is a group work, however, at the first, each student must propose their own solution in their group, then they have to evaluate all possible solutions as a group.

4. Students freely to choose the techniques of creative and rational methods to accomplish their design strategy.

5. Lecturers investigate the level of creativity of each students through application of the analytical rubric, as presented in Table 1.

6. Lecturers analyze the result of the assesments.

Table 1.Analytical rubric for assesment of creativity [7]

\begin{tabular}{|c|c|c|c|c|}
\hline Criteria & Very Creative (4) & Creative (3) & Ordinary (2) & Imitative (1) \\
\hline $\begin{array}{l}\text { Q1:Variety of } \\
\text { ideas and } \\
\text { contexts }\end{array}$ & $\begin{array}{l}\text { Ideas represent a } \\
\text { startling variety of } \\
\text { important concepts } \\
\text { from different } \\
\text { contexts or } \\
\text { disciplines. }\end{array}$ & $\begin{array}{l}\text { Ideas represent } \\
\text { important concepts } \\
\text { from different } \\
\text { contexts or } \\
\text { disciplines. }\end{array}$ & $\begin{array}{l}\text { Ideas represent } \\
\text { important concepts } \\
\text { from the same or } \\
\text { similar contexts or } \\
\text { disciplines. }\end{array}$ & $\begin{array}{l}\text { Ideas do not } \\
\text { represent important } \\
\text { concepts. }\end{array}$ \\
\hline $\begin{array}{l}\text { Q2: Variety of } \\
\text { sources }\end{array}$ & $\begin{array}{l}\text { Created product } \\
\text { draws on a wide } \\
\text { variety of sources, } \\
\text { including different } \\
\text { texts, media, } \\
\text { resource persons, } \\
\text { or personal } \\
\text { experiences. }\end{array}$ & $\begin{array}{l}\text { Created product } \\
\text { draws on a variety } \\
\text { of sources, } \\
\text { including different } \\
\text { texts, media, } \\
\text { resource persons, } \\
\text { or personal } \\
\text { experiences. }\end{array}$ & $\begin{array}{l}\text { Created product } \\
\text { draws on a limited } \\
\text { set of sources and } \\
\text { media. }\end{array}$ & $\begin{array}{l}\text { Created product } \\
\text { draws on only one } \\
\text { source or on } \\
\text { sources that are not } \\
\text { trustworthy or } \\
\text { appropriate. }\end{array}$ \\
\hline $\begin{array}{l}\text { Q3: Combining } \\
\text { ideas }\end{array}$ & $\begin{array}{l}\text { Ideas are combined } \\
\text { in original and } \\
\text { surprising ways to } \\
\text { solve a problem, } \\
\text { address an issue, or } \\
\text { make something } \\
\text { new. }\end{array}$ & $\begin{array}{l}\text { Ideas are combined } \\
\text { in original ways to } \\
\text { solve a problem, } \\
\text { address an issue, or } \\
\text { make something } \\
\text { new. }\end{array}$ & $\begin{array}{l}\text { Ideas are combined } \\
\text { in ways that are } \\
\text { derived from the } \\
\text { thinking of others } \\
\text { (for example, of the } \\
\text { authors in sources } \\
\text { consulted). }\end{array}$ & $\begin{array}{l}\text { Ideas are copied or } \\
\text { restated from the } \\
\text { sources consulted. }\end{array}$ \\
\hline $\begin{array}{l}\text { Q4: } \\
\text { Communicating } \\
\text { something new }\end{array}$ & $\begin{array}{l}\text { Created product is } \\
\text { interesting, new, or } \\
\text { helpful, making an } \\
\text { original } \\
\text { contribution that } \\
\text { includes } \\
\text { identifying a } \\
\text { previously } \\
\text { unknown problem, } \\
\text { issue, or purpose. }\end{array}$ & $\begin{array}{l}\text { Created product is } \\
\text { interesting, new, or } \\
\text { helpful, making an } \\
\text { original } \\
\text { contribution for its } \\
\text { intended purpose } \\
\text { (for example, } \\
\text { solving a problem } \\
\text { or addressing an } \\
\text { issue). }\end{array}$ & $\begin{array}{l}\text { Created product } \\
\text { serves its intended } \\
\text { purpose (for } \\
\text { example, solving a } \\
\text { problem or } \\
\text { addressing an } \\
\text { issue). }\end{array}$ & $\begin{array}{l}\text { Created product } \\
\text { does not serve its } \\
\text { intended purpose } \\
\text { (for example, } \\
\text { solving a problem } \\
\text { or addressing an } \\
\text { issue) }\end{array}$ \\
\hline
\end{tabular}


Table 2.Design strategy and values of creativity of each student

\begin{tabular}{|c|c|c|c|c|c|c|c|c|c|}
\hline \multirow{2}{*}{$\begin{array}{c}\text { Students/ } \\
\text { (Group) }\end{array}$} & \multirow{2}{*}{ Topics } & \multicolumn{3}{|c|}{ Design Strategy } & \multicolumn{4}{|c|}{ Rubric Cretivity } & \multirow[b]{2}{*}{ Total } \\
\hline & & Problem Exploration & Problem Specification & Generate Solution & Q1 & Q2 & Q3 & Q4 & \\
\hline $1610912036 /(1)$ & Beach Cleaner & $\begin{array}{l}\text { Brainstorming } \\
\text { Doing Survey }\end{array}$ & $\begin{array}{l}\text { Objective Tree } \\
\text { Performance Specification } \\
\text { Quality Function }\end{array}$ & Design by Drawing & 4 & 3 & 2 & 2 & 2,75 \\
\hline $1610912007 /(1)$ & Beach Cleaner & $\begin{array}{l}\text { Brainstorming } \\
\text { Doing Survey }\end{array}$ & \begin{tabular}{|l|} 
Objective Tree \\
Performance Specification \\
Quality Function \\
\end{tabular} & Design by Drawing & 3 & 3 & 3 & 2 & 2,75 \\
\hline 1610913002/(1) & Beach Cleaner & $\begin{array}{l}\text { Brainstorming } \\
\text { Doing Survey }\end{array}$ & \begin{tabular}{|l|} 
Objective Tree \\
Performance Specification \\
Quality Function \\
\end{tabular} & Design by Drawing & 3 & 3 & 3 & 3 & 3,00 \\
\hline $1610911056 /(2)$ & Floating Garbage Collector & Synetics (Direct Analogies) & Objective Tree & Design by Drawing & 4 & 3 & 3 & 3 & 3,25 \\
\hline $1610912032 /(2)$ & Floating Garbage Collector & Brainstorming & Objective Tree & $\begin{array}{l}\text { Morphological Chart } \\
\text { Design by Drawing }\end{array}$ & 2 & 3 & 2 & 2 & 2,25 \\
\hline $1610913021 /(3)$ & Fish Detector in Ocean & Brainstorming & Objective Tree & Design by Drawing & 3 & 3 & 2 & 2 & 2,5 \\
\hline $1610913042 /(3)$ & Fish Detector in Ocean & Brainstorming & Objcetive Tree & Design by Drawing & 3 & 3 & 2 & 2 & 2,5 \\
\hline $1610912029 /(3)$ & Fish Detector in Ocean & Brainstorming & Objective Tree & Design by Drawing & 3 & 3 & 2 & 2 & 2,5 \\
\hline $1610912020 /(4)$ & Floating Garbage Collector & Brainstorming & Objective Tree & $\begin{array}{l}\text { Morphological Chart } \\
\text { Design by Drawing } \\
\end{array}$ & 3 & 2 & 3 & 2 & 2,5 \\
\hline 1610913013/ (4) & Floating Garbage Collector & Brainstorming & Objective Tree & $\begin{array}{l}\text { Morphological Chart } \\
\text { Design by Drawing }\end{array}$ & 3 & 2 & 3 & 2 & 2,5 \\
\hline 1610913016/(4) & Floating Garbage Collector & Brainstorming & Objective Tree & $\begin{array}{l}\text { Morphological Chart } \\
\text { Design by Drawing } \\
\end{array}$ & 3 & 2 & 3 & 2 & 2,5 \\
\hline 1610912008/(5) & Garbage Trasher & Brainstorming & \begin{tabular}{|l|} 
Objective Tree \\
Performance Specification \\
Quality Function
\end{tabular} & Design by Drawing & 2 & 3 & 2 & 2 & 2,25 \\
\hline $1610912038 /(5)$ & Garbage Trasher & Brainstorming & $\begin{array}{l}\text { Objective Tree } \\
\text { Performance Specification } \\
\text { Quality Function }\end{array}$ & Design by Drawing & 2 & 3 & 2 & 2 & 2,25 \\
\hline 1610913014/(5) & Garbage Trasher & Brainstorming & $\begin{array}{l}\text { Objective Tree } \\
\text { Performance Specification } \\
\text { Quality Function }\end{array}$ & Design by Drawing & 3 & 3 & 3 & 2 & 2,75 \\
\hline & & & & Ave & 2,93 & 2,79 & 2,5 & 2,14 & 2,59 \\
\hline
\end{tabular}




\section{Results and Discussion}

The detail result of this research is shown in Table 2 . The result will be discussed in three areas. Firstly, to review the way of students in using several techniques to stimulate their creativity. Secondly, to calculate the level of creativity of students through application of analytical rubric given in Table 1 . The last, to observe the effectiveness of the applied techniques based on the resulted level of creativity.

\section{Review on Techniques used to Stimulate Creativity}

Based on Table 2, although students have shown their ability to use several techniques to stimulate creative thinking in correct way, however the used techniques are mostly dominated by brainstorming in exploring a problem, objectives tree in specifying a problem, and morphological chart methods and design drawing in generating solution. Unfortunatelly, other introduced techniques such as synetics and enlarging the search space are not used. At the beginning, students tried to explore their problem through applying a brainstorming technique. They made a listing of design statements that related to the problems including several solutions which have been existing in the market. Some students are creative enough to observe all important information related to their topics, but the others are less creative. The creative students also made a listing of weaknesses of the the existing solutions. Usually, for their proposed product later, they tried to overcome those weaknesses by their creative solutions. Some students even conducted a small survey to the related society to gather information about customer demands. From those collected information, students tried to specify the problem. Most of them used objective tree method, due to simplicity of the method in application. Some students even tried to make their ideas to be sharper by combining the objective tree with function analysis and quality function deployment.At the end, students proposed their solution by drawing their design mostly by hand although some of them have used an engineering softwares.

In general, the procedures of design that were taken by students have been correctly applied to assist them in finding a good solution for their problem. The difference among them is in term of quality of their collected data and their level of creativity for solutions.

\section{Level of Design Creativity of Students}

As seen in Table 2, the average attainment of the students isgenerally around 2.59. It means that the level creativity of the students is between category of Ordinary (Scale 2) and Creative (Scale 3). As seen in Table 1, there are 4 criteria of assesment of creativity [7]. Those are variety of ideas and context, variety of sources, combining ideas, and communicating something new. The rubric describes 4 levels of creativity: Very Creative (Scale 4), Creative (Scale 3), Ordinary (Scale 2) and Imitative (Scale 1). In the first criterion, students can be categorized in level of Creative due to their average attaiment is around 2.93. In the second criterion,the average attainment is 2.79. It is still in level Creative rather than Ordinary. The results indicate that students are creative enough in searching many information and use them to develop their creative ideas. However, in the third and fourth criterion, the average attainments areonly 2.5 and 2.15 respectively. For those criteria, the level creativity of students are categorized as Ordinary rather than Creative. The results indicate that students are still in ordinary levelin combining their ideas, because their ideasare mostly combined in ways that are derived from 
the thinking of others(for example:the authors of the sources). Students are also very ordinary in communicating something new, because their created productsonly servetheir intended purpose.(the products are not new).

\section{Effectiveness of The Applied Techniques in Stimulating Creativity}

From subchapter 4.2 can be seen that the average level of creativity is 2.59 . It can be said that the applied techniques, especially brainstorming and objective tree, are still not effective enough to stimulate the creativity of the students. The source of the problem is not in the method or technique, but basically because of the way of thinking of students in exploring the design problem and formulate the ideas. Although some students have shown their interesting creativity in design, but most our students are still in level of doing redesign of the existing products with small modifications. The solutions for modification are still in common engineering solutions, such as changing dimension, changing material of the product, changing performances of machines, etc.

\section{Conclusion}

Some points that can be concluded in this paper are as follow:

1. The students basically are able to use several design techniques to stimulate their creativity, especially techniques of brainstorming, objective tree and morphological chart method.

2. The level creativity of the students are measured through analytical rubric and the attainment for four used criteria: variety of ideas and context, variety of sources, combining ideas, and communicating something new, are 2.93, 2.79, 2.50 and 2.15 respectively. In general, the average level of student's creativity is 2.59 , somewhere between category of Creative (Scale 3 ) and Ordinary (Scale 2).

3. The way how to teach the creative thinking of students in the subject of Engineering Design in Department of Mechanical Engineering of Andalas University still need to evaluate and develop.

\section{References}

[1] Sternberg RJ, Lubart TI, Defying the crowd: Cultivating creativity in a culture of conformity. FreePress, New York. (1995)

[2] Li, Y; Wang, J; Li, X; Zhao, W; Design creativity in product innovation, International Journal Advance Manufacturing of Technology, Vol 33, pp. 213-222 (2007)

[3] Cross, N; Engineering Design Methods: Strategies for Product Design 3rd Edition, John Wiley \& Son, Ltd (2000)

[4] Yilmaz, S; Seifert, C.M; Gonzalez, R; Cognitive heuristics in design: Instructional strategies to increase creativity in idea generation, Artificial Intelligence for Engineering Design, Analysis and Manufacturing Vol. 24, 335-355 (2010)

[5] Hong, J; Jeoung, S; Cho, D; Idea generation Methodology for Creative Design Thinking, International Association of Societies of Design Research, The Hongkong Polytechnic University (2007) 
[6] Doris, C; Methods that may stimulate creativity and their use in architectural design education, International Journal Technology Design Education, Vol. 20,:pp.453-476 (2010)

[7] Brookhart S.M.; How to Create and Use Rubrics for Formative Assessment and Grading, ASCD (2013) 